Bryn Mawr College

Scholarship, Research, and Creative Work at Bryn Mawr College

2014

\title{
To Die with the Buddha: The Brick Pagoda and Its Role in the Xuezhuang Tomb in Early Medieval China
}

Jie Shi

Bryn Mawr College, jshi1@brynmawr.edu

Let us know how access to this document benefits you.

Follow this and additional works at: http://repository.brynmawr.edu/hart_pubs

Part of the History of Art, Architecture, and Archaeology Commons

\section{Custom Citation}

Shi, Jie. 2014. "To Die with the Buddha: The Brick Pagoda and Its Role in the Xuezhuang Tomb in Early Medieval China." T'oung Pao 100.4/5: 363-403.

This paper is posted at Scholarship, Research, and Creative Work at Bryn Mawr College. http://repository.brynmawr.edu/hart_pubs/79

For more information, please contact repository@brynmawr.edu. 
Shi, Jie. 2014. "To Die with the Buddha: The Brick Pagoda and Its Role in the Xuezhuang Tomb in Early Medieval China." T'oung Pao 100-4-5: 363-403. http://doi.org/10.1163/15685322$10045 \mathrm{P} 03$

T’oung Pao 100-4-5 (2014) 363-403

To Die with the Buddha: The Brick Pagoda and Its Role in the Xuezhuang Tomb in Early Medieval China

Jie Shi

Abstract: The important late fifth- or early sixth-century brick tomb at Xuezhuang in Dengxian (Henan) features a brick form at the rear wall, which remained mysterious until it has recently been shown to represent a Buddhist pagoda. This discovery sheds light on the purpose of the burial chamber, featuring the novel combination of vaulted ceiling, colonnade, and pagoda, as simulating an Indian-derived Buddhist temple (caitya). To reinforce this Buddhist context, the burial chamber simultaneously imitates the structure of a Buddhist votive stele (zaoxiangbei 造 像碑), in which various Buddhist images, including the Buddha and bodhisattvas, apsaras, worshippers, and guardians, are carefully organized. The Xuezhuang tomb thus merges Buddhist structures with the traditional Chinese funerary structure, representing an entirely new manner in which funerary art and Buddhist art interacted with one another in early medieval China. While in earlier times Buddhist elements were subject to the unilaterally dominant funerary context, in the fifth to sixth centuries, as the importance of a specifically Buddhist context increased, the tomb occupant, whose coffin lay right before the pagoda, became an integral part of a simulated Buddhist structure as a worshipper symbolically poised to worship the pagoda or attend the "dead" Buddha in the concealed Buddhist "temple" that was the tomb.

Résumé: La tombe importante, datant de la fin du ve siècle ou du début du vie, découverte à Xuezhang (Dengxian, Henan) comporte une forme en briques sur son mur postérieur dont on n'a montré que récemment qu'il s'agissait d'une pagode bouddhiste. Cette découverte éclaire l'objet de la chambre funéraire: la combinaison d'un plafond en voûte, d'une colonnade et d'une pagode évoque un temple bouddhiste de style indien (caitya). Renforçant encore ce contexte religieux, la chambre funéraire imite en même temps la structure d'une stèle votive bouddhiste (zaoxiangbei 造像碑), dans laquelle les images du Bouddha, des bodhisattvas, des apsaras, des adorateurs et des gardiens sont soigneusement disposées. La tombe de Xuezhang combine de la sorte des structures bouddhistes et une structure funéraire chinoise traditionnelle; elle représente une manière entièrement nouvelle dans la Chine du début du Moyen Âge, dans laquelle interagissent l'art funéraire et l'art bouddhique. Alors qu'auparavant les éléments bouddhistes étaient subordonnés à un contexte exclusivement funéraire, aux ve-vie siècles le contexte spécifiquement bouddhique a gagné en importance; en conséquence, l'occupant de la tombe, dont le cercueil était placé directement devant la pagode, est devenu partie intégrante d'une structure bouddhique simulée en tant qu'adorateur placé symboliquement pour faire ses dévotions à la pagode, ou alors être au service du Bouddha "mort" dans le temple bouddhique caché qu'était devenue la tombe. 
Keywords: Xuezhuang, tomb, architecture, Buddhism, pagoda, art

In 1958, in a small village called Xuezhuang 學莊 in Dengxian 鄧縣, in the south of Henan province, archaeologists opened a brick tomb that sheds light on a new kind of transreligious interaction between funerary art and Buddhist art, two of the most influential religious art traditions in early medieval China. ${ }^{1}$

Oriented to the south with a slight angle toward the east, this tomb, though damaged and plundered, is among the largest and most lavishly decorated tombs known from the period. It consists of an elongated rectangular burial chamber that measures over six meters long, three meters wide, and three meters high, approached by a nearly four-meter- long passage, which is slightly narrower and lower than the burial cham- ber (Fig. 1). The façade boasts a beautiful polychrome wall painting, and the interior faces of the walls feature painted mould-impressed clay tiles bearing raised images.

Based on the style of the architecture, the mural, the painted tiles, as well as the surviving grave goods, Su Bai 宿白 and Yang Hong 楊泓 have dated this tomb safely to no later than 548 ce and no earlier than the first half of the fifth century. ${ }^{2}$ An ink inscription written in handsome running script on a longer side of a brick in the tomb mentions a military campaign, suggesting that the anonymous tomb occupant was a military official native to $\mathrm{Wu}$ 吳 prefecture in presentday south Jiangsu province. ${ }^{3}$

The damages inflicted on the tomb are considerable: The barrel- vaulted ceilings of the main chamber and the passage have collapsed; the floor and the brick platform beneath the coffin are shattered; more than half of the pictorial tiles have fallen or disappeared; the coffin and the physical remains in it have vanished. Nevertheless, with its major structure standing firm, this tomb has been considered, since the day of its discovery, a significant work of early medieval Chinese art.

Despite a substantial amount of scholarship devoted to this tomb, including Annette Juliano's monograph titled Teng-hsien: An Important Six Dynasties Tomb (1980), a brick structure set in the rear wall of the burial chamber has escaped scholars' attention until quite recently.

Partially damaged, this brick structure is made of two parts, one on top of the other (see Fig. 1). The lower part comprises two identical brick pillars standing side by side. ${ }^{4}$ Above the pillars rests the superstructure, which is built of nine alternate rows of bricks (one row laid lengthwise, the next widthwise) beneath a pinnacle that no longer exists. ${ }^{5}$ The over- all shape of the brick structure looks almost like a multi-stepped ziggurat: whereas the pillars below stand upright, the superstructure sharpens at the top to fit into the narrowing crest of the vault. Rather than being totally solid, the brick structure is in fact "porous," interrupted by a regu- lar group of "holes"- spaces left unfilled by bricks - in the lengthwise rows. On each of these pierced rows, one larger hole in the shape of a ziggurat occupies the center, flanked symmetrically on both sides by two smaller rectangular ones. All these orchestrated details suggest a larger meaningful design.

Such a stepped structure was not exceptional during the fourth to sixth centuries in south China. During the past five decades excavations of approximately thirty tombs near present-day Nanjing 南京, Jiangsu province, and Echeng 鄂城, Hubei province, have brought to light dozens of analogous brick structures, constructed in similar positions, like forms, and in similar burial chambers. ${ }^{6}$ Among them the one in the better-preserved Zelin 澤林 Tomb 5 near Echeng features 
a special trapezoid brick with a sharp tip and a wide base. This upwardly pointing brick simulates a slim triangular pinnacle that crowns a stepped brick structure, an architectural feature almost exclusive to Buddhist pagodas at that time. ${ }^{7}$ These new discoveries enable scholars to identify these brick structures as imitations of the pagoda.

Although pagodas, as well as other Buddhist motifs, had already been introduced into Chinese tombs by the late second century, 8 the brick pagodas at Xuezhuang and other related tombs are fundamentally different from all those predecessors. Unlike the previous pagodas, which were either individual images or objects, the brick pagodas that interest us were built as an integral part of and in a meaningful position in a larger architectural structure. Layered with regular bricks, the same used for constructing the tomb, this morphologically simple, basic structure occupied arguably the most important space in the tomb - the rear wall, which as the backdrop of the deceased's coffin must have faced anyone who entered the tomb through the door. $^{9}$

But this discovery prompts a larger, previously unexplored question: what are these Buddhist pagodas doing in Chinese tombs? Being the Chinese version of Indian stuppas, ${ }^{10}$ the pagoda stood for the Buddha Śākyamuni's body and personhood after his earthly death, or nirvāna, and therefore was extensively commissioned and worshipped by Buddhist laymen and monks. ${ }^{11}$ Meanwhile, tombs represented the final resting place of the deceased in the centurieslong Chinese tradition of ancestral worship. ${ }^{12}$ How did the two different religious traditions coex- ist and interact with one another in the same architectural space?

It appears that whereas Buddhist elements in early Chinese tombs, particularly those during the Eastern Han dynasty (25-220), appeared as individual motifs without a unified Buddhist context, the Xuezhuang pagoda in the Six Dynasties served as an organic part of a complex architectural space that simulated Buddhist structures, which were meshed with the traditional funerary structure to serve a complex pur- pose of the deceased. ${ }^{13}$ More specifically, the Xuezhuang tomb's overall design, hinged upon the pagoda, organizes three artistic traditions in the tomb, including the exotic Indian-derived Buddhist temple, the Buddhist votive stele (zaoxiangbei 造像碑), and the decorated burial with wall paintings (bihuamu 壁畫墓) or mouldimpressed clay tiles (huaxiangzhuanmu 畫像磚墓). Unlike the Eastern Han Buddhist motifs that were subdued to a dominantly funerary context, ${ }^{14}$ the Xue- zhuang brick pagoda plays a key role in a new kind of Buddhist intervention in the traditional Chinese religion of ancestral worship, situating the deceased in a definite Buddhist context and identifying him not only as a family ancestor but also as a disciple of the Buddha.

Traditional formalism and iconography, though proven effective in the Eastern Han cases, tend to ignore the relationships between individual elements and therefore are insufficient to deal with the early medieval case. ${ }^{15}$ In what follows we focus instead on the embedded structures that encompass individual elements in the entire brick chamber, including architecture (of which the brick pagoda is a part), painting, and the deceased's body.

\section{The Chamber as Buddhist Temple}

Instead of being an isolated Buddhist icon, the pagoda set in the rear wall of the Xuezhuang tomb is integral to a large architectural structure, which reflects its debt to the Buddhist temple in contemporary India. ${ }^{16}$ 
The plinth of the pagoda formed of two brick pillars, as already men- tioned, is related to twenty-two brick pillars forming eleven facing pairs along the two side walls of the tomb (see Fig. 1). Each of these evenly spaced side pillars resembles the two rear pillars of the pagoda plinth in both form and structure, except for measuring a few inches narrower. ${ }^{17}$ The uniformity, consistency, and evenness of these pillars weaves the pagoda into a rectangular colonnade. ${ }^{18}$

Although brick pillars had already made their appearance in Chinese tombs along the two side walls by the late second or early third century, they were used then for a different purpose: to reinforce the tomb structure, or, to divide the interior space into a front chamber (qianshi 前室 ) and a back chamber (houshi 後室). ${ }^{19}$ The pillars in colonnades at Xuezhuang and other tombs during the fourth to fifth centuries, however, are significantly different. Each pair of the side pillars supports an arch as a rib of the barrel-vaulted ceiling; the tomb is no longer divided into front and rear chambers, but is a continuous colonnaded hall. ${ }^{20}$ As some architectural historians have observed, some of these tombs are so small that the arches spanning the pilasters "are structurally unnecessary" for the purpose of strengthening the tomb. ${ }^{21}$ Obviously, these pillars are just adornments for the interior of the tomb.

The new pillars in colonnades coincided with the first emergence of the brick stūpa or pagoda at the rear wall of single-chamber tombs in the Echeng area. And during the early fifth century, as the Xuezhuang tomb shows, the brick pagoda began organically meshing into the colonnade, with the rear pillars turned into a pagoda plinth, upon which the storeys and pinnacle stood. ${ }^{22}$ A better-preserved example of this new development is Zelin Tomb 6, in which the three major architectural elements, including the barrel-vaulted ceiling, the colonnade of pillars - in this case slightly battered - and the brick pagoda, remained in an intact unity when the tomb was excavated. $^{23}$

Although the combination of vaulted ceiling, colonnade, and pagoda was unknown in indigenous Chinese architecture prior to this period, it characterizes the Indian Buddhist temple called caitya (or, chaitya-hall, or, chetiya-ghara), a Buddhist temple with a stūpa inside. ${ }^{24}$ Scholars have identified three major types of caityas in west and central India, among which the best-known is a group of apsidal rock temples constructed between $200 \mathrm{BCE}$ and $200 \mathrm{ce} .{ }^{25} \mathrm{Cut}$ into mountain cliffs in Bhājā, Kondane, Ajanțāa, and Pitalkhorā, these caityas are still open to Buddhist devotees for worshipping the stūpa.26 Imitating a wooden- structure archetype, a typical rock-cut cave caitya comprises an arched doorway, a rectangular barrel-vaulted hall (nave) in the front, and a small domed circular chamber housing a solid freestanding stūpa in the rear. While the spacious front hall accommodates worshippers during ritual gatherings, the rear chamber enshrines the cultic object. ${ }^{27}$ In the later basilica type of caityas in Bhājā, Ajaṇtā, Nasik, Bedsāa, and Kārlā, the interior of the apsidal temple is decorated by a colonnade of pillars from the side and the back (Fig. 2) ${ }^{28}$ Resting above the colonnade is a series of arches that symbolically support the ceiling. Although most Indian caityas are apsidal, the rear of these temples can be rectangular, too, reminiscent of the Xuezhuang tomb. Like the apsidal ones, each of these quadrangular caityas also enshrines a stūpa in the rear. It should be noted that later Indian caitya caves sometimes include a Buddha statue right in front of the stūpa (or carved into the front side of it) ${ }^{29}$ In this modified version, the Buddha image faces the worshipper as the main cultic image, which partially shadows the stūpa behind. The Buddha image, however, was somehow omitted at Xuezhuang, for reasons I will discuss later in this essay. 
Regardless of minor formal variations, three major structural similarities tie these Indian rock-cut Buddhist temples to the Chinese brick tombs represented by the Xuezhuang tomb: a single barrel-vaulted chamber with an elongated rectangular plan, a colonnade enclosed on all but the front sides, and a stūpa or pagoda in the rear.

These cross-cultural similarities become more explicit when the Chinese brick tombs including the Xuezhuang tomb are compared to Indian freestanding brick caityas, which are even closer to the Chinese brick tombs in material, dating, size, and structure. The two apsidal shrines at Ter (or Tagara) and Chezārla (the Kapoteśvara temple) in south India are two such rare examples that stand firm on the ground till this day. ${ }^{30}$ Although Susan Huntington dates both buildings to about the third century, a few other scholars including Ananda K. Coomaraswamy, Percy Brown, and Adam Hardy prefer a relatively later date about the fifth or the early sixth century, which makes the two Indian shrines exactly contemporaneous with the Chinese tombs under discussion. ${ }^{31}$ Unlike most of their monumental rock-cut counterparts, these brick temples are relatively small, measuring about seven meters long, right about the average length of the Chinese brick tombs including the Xuezhuang tomb. ${ }^{32}$ In structure these brick caityas feature a barrel-vaulted ceiling, rounded at the rear end, a gabled-end of caitya-window form (façade), and walls decorated with simple pillars. A dominant opinion holds that each of the brick apsidal shrines before its later conversion to Hinduism once enshrined a Buddhist stūpa in the rear, like their rock-cut counter- parts introduced above. ${ }^{33}$ All of these characterize the Indian rock-cut Buddhist temples as well. ${ }^{34}$

The front gabled-end of the Indian caityas illuminates a previously ignored detail of the painted façade at Xuezhuang that is otherwise difficult to interpret. In many Indian rock-cut caityas the ends of longitudinal beams, shaped like teeth, project and rest upon the tops of the two pillars of the door, forming a toothed arc. This functionally useless element reflects the intention of simulating a wooden-structure caitya (see Fig. 2). ${ }^{35}$ In the Xuezhuang tomb a typical toothed arc was reproduced faithfully on the outer arching of the façade, which is divided into five sections by four evenly spaced rectangular bars. Each of the bars consists of two connected, square, painted mould-impressed tiles decorated with flower patterns (Fig. 3). This distinct toothed arc, absent from early Chinese tombs or aboveground architecture to my knowledge, was most likely inspired, either directly or indirectly, by Indian caityas. ${ }^{36}$

We can only speculate, however, on the route by which the Indian prototypes entered China, due to the current lack of archaeological evidence. Because such barrel-vaulted, colonnaded brick tombs with pagodas in the rear were exclusively located in or near such major metropolises as Wuchang 武昌 (25 miles to the west of Echeng, 260 miles to the southeast of Dengzhou) and Jiankang 建康 (present-day Nan-jing) in the middle and lower Yangzi River valleys, it is likely that the foreign model first reached the southeast coast of China by sea before it spread from there upstream along the Yangzi River. ${ }^{37}$

The significance of the Xuezhuang and other tombs that imitate the exotic Buddhist temple must not be underestimated. Whereas during the Eastern Han dynasty tomb designers only selected individual Buddhist images, such as the Buddha, relics, white elephants, and pagodas, and inserted them into the tomb as decorations, the Xuezhuang designer turned the whole tomb into a Buddhist structure, in this case an Indian caitya, albeit with more or less modification. Through the transformation of the Indian prototype to the Chinese simulation, an initially aboveground structure was turned underground, and an open Buddhist temple became a concealed realm no one could access once the door had been closed. ${ }^{38}$ In doing so, the designer 
situated the deceased's body within the Buddhist structure, where a Buddhist worship- per should normally be.

This design renders the nature of the tomb chambers ambiguous. Were these brick structures meant to be Buddhist temples or burials? Which context was primary, the funerary one or the Buddhist one? If the chamber was primarily meant to be a hidden Buddhist temple, then the deceased was hardly the real master or occupant of the structure, which was dedicated to the Buddha. It seems that the familiar situation in pre- Buddhist China, in which a tomb was always the posthumous dwelling of the deceased, was in this early medieval case no longer an indisputable fact. So was the dominance of funerary context. The Buddhist con- text becomes even stronger when it turns out, as we shall see in the following section, that the whole Xuezhuang tomb was simultaneously designed to simulate another popular Buddhist structure: the votive stele (zaoxiangbei).

\section{The Chamber as Simulated Buddhist "Stele"}

At Xuezhuang the brick pagoda was not only the focal point of the In- dic-derived Buddhist architectural structure but also the centerpiece of another sculptural structure that simulates a Buddhist votive stele.

Buddhist votive steles became an artistic tradition in China no later than the late fourth century. Commissioned in the thousands, among which hundreds survive, these steles are largely formulaic in form, iconography, and structure. Shaped like a reversed letter U, these steles, carved in stone, are in fact sculptures with images or inscriptions on both sides. While the back side often bears minor engravings, the front side comprises a set of high-relief images positioned in a nearly triangle format.39 The center of these sculptures is always reserved for the main icon, a seated or standing Buddha highlighted by a radiating nimbus behind. ${ }^{40} \mathrm{He}$ is surrounded by apsaras over his shoulders, bodhisattvas on his sides, and guardian lions, donors or worshippers, and such ritual objects as incense-burners (boshanlu 博山爐) or hu 壼 vases below his feet.

The votive "stele" at Xuezhuang, however, is not so simple, because it is not a real sculpture, but rather a simulated one constituted jointly by three seemingly disparate components spread across the brick chamber: the mural painted in the front of the simulated temple, a group of painted tiles set in the walls, and the brick pagoda at the rear. As I will demonstrate below, to put all these components together and generate a unified image of a votive stele, the viewer must stand before the entrance to face it head on and take a so-called transparent view, which guides his or her eyes to penetrate the arched entrance through the nave until they reach the rear wall, projecting all the images imaginarily around the pagoda.

To such a viewer, the mural, panted on the reversed U-shaped façade that embraces the entry hole, is the nearest component (Fig. 3, see Fig. 1). The mural's arching contour clearly resembles the nimbus or aureole of a Buddhist votive stele. The curving painted band is divided into three levels by the four exotic "teeth" projecting inward from the outer rim of the arch, as discussed above. From top to bottom these levels are filled, respectively, by a monstrous head, two flying apsaras, and a pair of warriors.

To better articulate the similarity, a concrete example is necessary. Among the uncovered Buddhist steles of this type, one commissioned by Sun Baoxi 孫寶禧 in the year 518 stands out as a close comparison to the Xuezhuang mural in both form and dating (Fig. 4).41 In this limestone sculpture, measuring 1.52 meters tall, roughly half the height of 
the Xuezhuang chamber, the Buddha stands in the middle with an arching aureole behind his back and a circular halo behind his head. The halo, in shape of a rosette, is held by a frontal-pose horned monster, identified as either dragon or Nāga, whose reversed Y-shaped tongue sticks out of its mouth and hooks up the upper outer rim of the halo. Below the dragon is a pair of apsaras flying above the Buddha's shoulders, each holding offerings in their hands. Further below the apsaras two bodhisattvas flank the Buddha at both sides.

At Xuezhuang, despite the omission of the central Buddha and the flanking bodhisattvas, the whole structure of a votive stele, also in shape of an arch, remains nevertheless complete.

Three major elements take their respective positions: the monstrous head above, the flying ladies in the middle, and the flanking attendants or guardians below.

The frontal-pose monstrous head at the top of the painted arch is almost immediately reminiscent of the zoomorphic mask called pushou 鋪首 or taotie 饕䬸, a favorite motif in early and medieval Chinese art (see Fig. 4). ${ }^{42}$ It has a pair of red horns, two dark bulging eyes, and a maroon protruding snout, upon which a couple of white ribbon-shaped hairs curve upward. Used to ward off evil, this mask often decorated the doorway of tombs. The iconographies all derived from the Chinese ico- nography of the dragon, whose powerful wings could take the deceased's souls up to heaven in the state of immortality.43 In an Indic context, however, this monster was akin to the serpent King Nāga. Legend has it that the Indic serpent demigod Nāga sheltered the Buddha Śākyamuni with his hood when the Buddha-to-be was meditating under the Bodhi tree.44 Perhaps a marriage of the two traditions, from the late fifth cen- tury onwards, representations of intertwining dragons holding the Bud- dha's halo, or a canopy, umbrella, or roof of the tent that shelters the Buddha's head, in their mouths or with their out-sticking tongues be- came widespread in all types of Buddhist sculptures, paintings, or cave temples in China.

As a variation of the conventional Nāga or dragon motif, the zoomorphic head in the Xuezhuang mural holds a horizontal stick between its white, sharp fangs (see Fig. 3). Wound with brown ribbons, the stick with both ends decorated by rosettes is called sheng 勝, a Daoist token associated with immortality. ${ }^{45}$ The Chinese sheng was used to replace the Buddha's halo (also rendered into a rosette), which clearly lost its raison d'être in the absence of the Buddha. ${ }^{46}$

Below the monstrous head, the flying ladies are sinicized versions of Indian apsaras, or celestial dancers, whose iconography was introduced into China about the early fifth century. ${ }^{47}$ Whereas in Indian mythology apsaras are demigods who entertain gods in the court of Indra, in China these graceful dancers were best known in the Buddhist context asheavenly people" (tianren 天人), who tossed auspicious flowers as a sign of blessing. In Buddhist context, it is related in the Vimalakīrti- nirdeśa-sūtra that the stimulating debate between Vimalakīrti and Mañjuśrī on the Buddhist Law attracted apsaras to scatter heavenly flowers over the bodhisattvas and major disciples. ${ }^{48}$

Another example of Chinese intervention of the Buddhist structure, the warriors below the apsaras take the place of the bodhisattvas in a standard Buddhist votive stele (see Figs. 3, 4). Portrayed in three-quarter view, the two warriors form a strict pair of mirror images, both facing toward the entrance. With a broader face and flatter roof of the nose, they display typical Chinese physical features. In blue hats, brown armor, red robes, white pants, and black shoes characterized with an up- turned front end, their clothing is unmistakably Chinese, too. 
During this period, whereas warriors were usually portrayed with different physical features in funerary and Buddhist contexts, they played a common role as doorkeepers, and therefore occasionally became each other's substitutes. By the early sixth century, almost identical Chinese- looking warriors with similar armor and with identical swords in their hands had become a regular motif to flank the entrance to Chinese tombs. Meanwhile, pairs of warriors (normally called Guardian Kings, Lokapālas, or in Chinese tianwang 天王) with non-Chinese physical features, including deep-set eyes and aquiline noses, guard the entranc- es to many Buddhist caves holding non-Chinese magic weapons. Al- though in most cases these two kinds of door guardians were not interchangeable, the Chinese guardians, as Li Song has discovered, make their appearance in at least one of the Buddhist caves at Maijishan 麥積 山 in present-day Tianshui 天水, Gansu province, dated likewise to the late fifth to early sixth centuries. ${ }^{49}$ As another example of synthesizing funerary and Buddhist art traditions, the Xuezhuang guardians probably functioned as the protectors of both a burial and a Buddhist sacred structure, in which the pagoda stood.

Although the most important element in the votive stele, the Buddha (along with the attending bodhisattvas), is missing from the mural, this void in the entry hole is filled by the pagoda in a special perspective. If we imagine the mural projected horizontally onto the rear wall, the Buddha's position is taken by the pagoda while the bodhisattvas are eclipsed by the warriors (Fig. 5). The arching contour of the façade merges perfectly with that of the nimbus attached to the back of the vo- tive stele (Fig. 5, see Figs. 1, 4). The equality between the Buddha and the pagoda was part of the Buddhist art tradition. It was common to use stūpas instead of Buddha images as the main cultic object in early Buddhist caitya temples and early bas-reliefs in India, such as those at Sāñchī, Bhārhut, and Nasik. ${ }^{50}$ A Chinese votive stele, dated perhaps to the late fifth century, bears a bas-relief of a three-story pagoda on its back side, while on its front side a seated Buddha is flanked on the left by a bodhisattva standing en face and on the right by another bodhisat- tva in profile. ${ }^{51}$ It seems that the artist of this stele creatively took advan- tage of the two sides of the nimbus to let both the pagoda and the Buddha image share the same dominant position without excluding either, although the pagoda remains in the rear, as does its counterpart at Xuezhuang. ${ }^{52}$

This perspective, in which three-dimensional structures can be pro- jected onto twodimensional pictures, emerged in the Han dynasty and became common in the early medieval Chinese visual habit. ${ }^{53}$ By imagining oneself as seeing through the picture plane and reaching things behind it, the informed viewer can assemble the visible and invisible things together cognitively and construct an imaginary picture of all things projected onto their relative, right positions.

This transparent view, which reduces the depth of the architectural space to zero, stitches together the rear pagoda and the front mural with the middle Buddhist-themed images painted on mould-impressed tiles set in the side walls at Xuezhuang. Although upon discovery a number of the Xuezhuang painted tiles were out of place, either fallen onto the floor or permanently missing due to robbery, once the displaced tiles are put back in their original locations, they too fit into the simulated votive "stele" in the transparent view.

According to my reconstruction, explained in the Appendix, the Buddhist images along the walls fall into a rather fixed structure.

At the top level a tile of two confronting dragons, an iconographic equivalent to the monstrous head, appears in the north end of the upper register of the east wall, close to the pagoda. ${ }^{54}$ Three tiles of apsaras are symmetrically set in the upper register of the east and west 
pillars. Among them, two clearly form a pair: one represents two apsaras face- to-face flanking a hu vase, and the other depicts almost identical apsaras in an identical pose, only to flank an incense-burner on a lotus throne. ${ }^{55}$ The third tile (with inscription tianren 天人) shows a couple of apsaras, one beating a drum and the other dancing. ${ }^{56}$ Because ap- saras usually appear in pairs, it is reasonable to assume that a fourth brick might have once existed.

At the bottom level are the images of twenty-six identical warriors. Set in the lowest level of all pillars in the east, west, and north (rear) walls, these mould-impressed warriors display almost identical bodily features and costumes with those of the painted ones in the front mural, except for the total frontal view. ${ }^{57}$

The regulation becomes easy to understand in the transparent view that projects all images across the nave onto the rear wall. The Buddhist- themed tiles work in tandem with the front mural and the rear pagoda to simulate a votive stele. The apsaras and dragons fly above; the warriors guard below. Their symmetrical positions along the side walls fol- low the central axis of the tomb, which runs between the front mural and the rear pagoda. Maned lions (simha), missing from the mural but engraved on the plinth of the 518 stele below the Buddha, are substituted by the two painted tiles of confronting lions set respectively in the first pair of pillars in the passageway (see Figs. 4, 5) ${ }^{58}$ Derived from the Iranian-Indian tradition as a symbol for the regality, strength, and power of the Buddha, lions were another constant motif in votive steles.59 As- suming the walls became transparent, the lions would appear as if crouching at the two sides of the entrance in a symmetrical manner, reminiscent of the lions below the Buddhist votive stele (see Fig. 4).

In the transparent view another element - the worshipper-present in the 518 and many other Buddhist votive steles can be identified in the Xuezhuang chamber. The position of the worshippers engraved below the main Buddha on the plinth of the stele is taken by the deceased's coffin laid on the floor in front of the rear wall (Fig. 5, see Figs. 1, 4). In this way the artist has literally situated the deceased as a worshipper before the pagoda, though in a recumbent position rather than kneeling or sitting as normally represented in real votive steles.

However, a few other elements have been displaced so much that they require more imagination to be restored to the simulated votive "stele." For example, the incense burner carved on the plinth of the 518 stele echoes the identical boshanlu held in the hands of two attendants in a tile from Xuezhuang. ${ }^{60}$ What's more, images of numerous lotus flowers, symbols of fortune, purity, enlightenment, and rebirth in Buddhism, bloom in various forms everywhere on the mural and tiles across the tomb chamber, as they do in many votive steles. ${ }^{61}$ Due to the disrup- tion of the tomb, a majority of the burial objects have been lost, making it impossible to assess their roles in the simulated votive "stele." However, the major elements of an imagined votive stele are included in the simulated caitya approximately in their right places.

The transparent view, which allows the viewer's eyes to travel through this simulated Buddhist temple, generates a unified image of an imaginary votive stele by convening and superimposing images from different vertical sections along the side walls (Fig. 6). ${ }^{62}$ This view compresses a deep architectural space — the simulated Buddhist hall—into a relatively shallow pictorial space - the votive stele. From a reversed point of view, it is also valid to argue that the artist might have horizontally stretched a real votive stele lengthwise to fit it into the elongated caitya hall. Both views are of equal value in terms of perceptual conversion between threedimensional and two-dimensional spaces. In any event, all Buddhist structures, including the simulated caitya hall and votive "stele," are directionless: they are symmetrical between the left and the right of the vertical central axis of the rear pagoda. This absolute symmetry conveys a 
sense of solemnity, stability, and changelessness that might evoke religious awe in the Buddhist mind.

One may wonder why the designer took so much trouble to make such a complex simulated "stele" without considering some other alter- natives. For example, it would have been much simpler to directly insert an image of a votive stele, or even a genuine piece, into the chamber. The decision probably betrays the designer's intention of transforming the whole underground brick chamber into a virtual votive stele, for in this way the deceased's body would be situated within the Buddhist stele and be part of it. But if the brick chamber had to simulate both a Buddhist temple and a votive stele, an obvious morphological gap needs to be bridged, because while the former is a deep horizontal structure that opens in the front and that ends with the pagoda at the rear, the latter is a relatively flat vertical structure constructed around a Buddha image in the center. To bridge it, such stretching and distortion as discussed above is inevitable.

Eventually, the complex simulation must be activated through the viewer's informed penetrating eyes, which would assemble the rear pagoda, the images in the mural and along the walls into a three-dimensional simulation of a Buddhist votive stele, with the Buddha being replaced by the pagoda, and the deceased being situated as if worshipping the pagoda in a simulated Buddhist temple.

The Pagoda: Imperishable Body of the Buddha

Being integral to the larger Buddhist visual structures at Xuezhuang, the brick pagoda had a definite Buddhist meaning, unlike the decontextualized Buddhist-looking images in Eastern Han tombs. Yet the Buddhist simulations per se do not answer the following question: if in the transparent view the Buddha image in the sculptural space must conflict with the pagoda in the architectural space, then what makes the pagoda rather than the Buddha image dominant?

This question echoes with the previous problem in the architectural space: why did not the Xuezhuang designer follow some later caityas by including a Buddha image in front of the stūpa or pagoda?63 It must be noted again that Buddhist icons were introduced into Chinese tombs already in the late second century, and during the fifth to sixth centuries various Buddhist icons had al- ready dominated Chinese Buddhist caves and probably temples. These facts made the triumph of the seemingly outdated aniconic pagoda and the rejection of the fashionable Buddha image even more puzzling.

What fundamentally distinguishes the stūpa or pagoda from a Bud-dhist icon is the former's metaphysical nature as the imperishable Dhar- ma body of the Buddha.

Although the idea that the stūpa represents the Buddha was not new, it acquired a certain metaphysical meaning for a school of sutra exegetes in China known as "lecturers of nirvāna" (niepanshi 涅槃師), who ascended the stage of Chinese Buddhist history about the late fourth and early fifth centuries. It was also during this period that the Mahāparinirvāna-sūtra (Daboniepanjing 大般若涅槃經), the major canon of the nirvāṇa school, became widespread in China. ${ }^{64}$ To the nirvāna school, the cult of the stūpa after the earthly death of the Bud- dha Sākyamuni was vital, for the stūpa containing the relics of the Bud- dha was more than a symbol in memory of Śākyamuni; it was the imperishable Buddha or Dharma Body ( fashen 法身) that permanently dwells and never changes. ${ }^{65}$ The nirvāna teaching was extensively preached along the Yangzi Riv- er valley throughout the Southern Dynasties (420-589). As many as forty-seven Buddhist exegetes called sutra masters ( jingshi 經師) are recorded as having notably preached 
the nirvāna doctrine during this period. At least two of them were monastery abbots based in Jingzhou 荊州 prefecture, where Xuezhuang was located. ${ }^{66}$

The pagoda was not only considered the permanent Buddha but also, different from other Buddhist symbols such as the bodhi-tree, the wheel, or the footprint, was a physical marker of the burial. In India as early as the Vedic Age stūpas were built to house the physical remains of venerated lords or sages. Archaeologically, early Indian uses of stūpas for cremation burials date from the late second millennium BCE, long before Buddhism was born, and continued into the Buddhist era. ${ }^{67}$ After the death of Śākyamuni, stūpas that reputedly contained his relics were constructed in memory of him throughout the Buddhist world. Because the pagoda was a burial marker, it could fit into the Chinese funerary structure more harmoniously than a Buddha image could.

The idea of the permanent Buddha embodied by a funerary marker coheres perfectly with the traditional Chinese belief in "posthumous immortality" in the tomb.68 After a person dies, he or she would be eventually rewarded with what had not been achieved in life: becoming deathless by means of art, which portrays him or her as immortal. In Han tombs, numerous paintings and stone carvings portrayed the tomb occupants as riding dragons, phoenixes, or airborne chariots to paradise, where deathless deities or Immortals such as the Queen Mother of the West (Xiwangmu 西王母) resided. ${ }^{69}$ With the interred pagoda, both the Buddha and the deceased become immortal side-by-side in the simulated Buddhist hall as burial.

\section{The Chamber as Traditional Chinese Burial}

At Xuezhuang the funerary structure, which overlaps with the Buddhist architectural and sculptural structures, maintained the underground brick chamber as a traditional burial that focused on the deceased's rather than the Buddha's being. The funerary structure at Xuezhuang includes a group of painted tiles set in the walls, which goes beyond the Buddhist category and belongs in the centuries-long Chinese tradition of funerary art culminating in the Han dynasty. The tiles can be divided into two subgroups. The virtuous paragons, sometimes called "historical illustrations" (lishi gushi 歷史故事) by art historians, are set symmetrically on the two sidewalls toward the rear of the chamber; a ceremonial procession advancing from the rear to the front along the side-walls suggests a dynamic out- bound movement.

The first group of historical illustrations combines popular pictorial motifs familiar in the fifth and sixth centuries in Chinese tombs, both north and south. The extant three pieces in this group at Xuezhuang include two narrative illustrations of Guo Ju 郭巨 and Laolaizi 老萊子 and another of the "Four Greybeards from South Mountain" (Nanshan sihao 南山四皓). ${ }^{70}$ These first two stories portray two extraordinarily filial paragons, who famously served their parents and were especially welcome in the territory of Northern Wei, whose emperors promoted filial piety as state ideology. ${ }^{71}$ One tile represents Guo Ju, who, plagued by poverty, decided to bury his little son alive in order to save his limited food to feed his mother; the other depicts Laolaizi, who in old age dressed himself as a cute young child to amuse his elderly parents. ${ }^{72}$ The third illustration is of the Four Greybeards, a model of both good public service and reclusion. ${ }^{73}$ Once advising Emperor Hui of the Western Han, these politically wise men later became Daoist sages. ${ }^{74}$ In both northern and southern tombs, these virtuous paragons are always positioned on the side walls to flank the deceased's body. ${ }^{75}$ At Xuezhuang, in a similar 
fashion, they stay close to the deceased's coffin and perhaps refer to the tomb occupant's moral identification.

Accompanying the deceased with moral exemplars was a legacy of the funerary art of the Han dynasty. ${ }^{76}$ A distinguished Confucian scholar named Zhao Qi 趙岐 (108-201), while preparing for his own burial, is said to have painted images of four Confucian personalities, including Ji Zha 季札, Zichan 子產, Yan Ying 晏嬰, and Shuxiang 叔向, next to his

own portrait. ${ }^{77}$ This idea of paralleling (i.e., identifying) virtuous para- gons with the deceased continued into the sixth century. ${ }^{78}$

The second group of non-Buddhist images at Xuezhuang, the out- bound procession set in the two side walls, was one of the most tradi- tional motifs in Chinese funerary art. Split into two parallel arrays along the two walls, the procession, guided by the Four Directional Deities (sishen 四神), marches away from the coffin toward the chamber's entrance. At the center of the procession are unoccupied ox-carts and rid- erless horses, which were supposed to carry the invisible souls of the deceased (Fig. 7, see also Appendix). ${ }^{79}$

The Four Directional Gods, symbolized by the Green Dragon of the East, the White Tiger of the West, the Dark Warrior of the North, and the Red Bird of the South, had remained a regular motif in Chinese tombs since the Western Han as guardians of the four cardinal directions and protectors of the afterlife. 80 The winged dragon and tiger roam fero- ciously among the clouds toward the entrance in a dynamic movement on the two side walls. ${ }^{81}$ The Dark Warrior, portrayed as a turtle wound round with a snake, is set in the rear wall directly above the front-pose warriors (see Appendix). ${ }^{82}$ The winged unicorn (by inscription qilin 騏 驎), though not one of the Four Directional Gods, was often added to the group as representing the center direction, to form the so-called Five Spirits (wuling 五靈). ${ }^{83}$

Led by these supernatural deities are members of a magnificent pro- cession, which includes soldiers, musicians, dancers, offering holders, horse grooms, palanquin-carriers, ox-cart drivers, and others seeming to accompany the deceased's soul on an outing.

The soldiers wearing small hats or kerchiefs, flared sleeves, and bell- bottomed pants, all march on foot in straight columns. One tile represents four soldiers in one line, carrying swords or bows on their left shoulders or holding shields in their right hands. Another tile divides into two lines four identical-looking soldiers, each armed with a stick in the right hand while stretching the left arm forward with palm turned outward. It is probable that these armed persons were to be thought of as policing the way. Earlier archetypes of such soldiers were painted in Anak Tomb 3 in present-day Hwanghaenamedo, North Korea, dated to the mid-fourth century. In a large polychrome wall painting represent- ing an outbound procession on the eastern wall of the tomb's rear cham- ber, the central carriage of the tomb occupant is under the escort of a large group of soldiers marching in columns while carrying swords, shields, bows, or banners on their shoulders. The soldiers' military gear and physical postures all resemble their counterparts at Xuezhuang. ${ }^{84}$

The musicians, dressed in a similar manner as the soldiers, parade while performing. In one tile, five musicians are lined up playing the flute, the piccolo, and a long curving pipe. In a second tile, another group of four players wear flat circular drums attached to their waists. Each holds a drumstick in his right hand and a third object with a long handle and a bulging headperhaps a rattle-drum - in his left hand. Often seen as members of the funerary procession, such 
wind and percussion (guchui 鼓吹) musicians were common motifs in contemporary Chinese tombs in both the north and the south.85 The dancing performance in a third tile is led by a bearded man in a long robe stomp- ing the ground while brandishing a fan with his left hand and a tasseled cane with his right. Behind him stand an array of four people, one holding a feathered fan, and others making gestures.

There are also tiles that represent attendants holding ritual offerings, including canopies and incense-burners with opened-up lids, a traditional funerary motif that is known from as early as the first century BCE. ${ }^{86}$ And others are carrying personal paraphernalia such as a feathered fan, a folded cushion or mat, and other unidentifiable small portable items. Similar objects appear in the hands of attendants following a male master on an outing, portrayed in a decorated brick tomb at Tian-shecun 田舍村, in present-day Changzhou, Jiangsu province. ${ }^{87}$

In the entire Xuezhuang procession what directly addresses the de- ceased includes several tiles of unoccupied ox-carts, empty palanquins, and riderless horses led by grooms. ${ }^{88}$ Oriented to the outside of the buri- al, these empty vehicles and horses, as forms of the mobile "spirit seat," provide transportation for the deceased in the afterlife. ${ }^{89}$ The empty positions presumably allude to the invisible being of deceased ancestors, as believed among people of the time. ${ }^{90}$ Such paired images of the riderless horse and ox-cart, which did not gain popularity in tombs until the post-Han era, made their first appearances in Eastern Han funerary bas- reliefs. ${ }^{91}$

With the systematic introduction of the funerary motifs along the walls, the designer's intention is unmistakable: to decorate the brick structure at Xuezhuang as a traditional Chinese burial. Thus the conventional organization of the images was strictly followed. For example, the virtuous paragons appear, as always, at the rear of the side walls to flank the deceased's coffin; the Dark Warrior in the North, corresponding to the Back (houfang 後方) in the Chinese system of directions, is set in the rear wall (see Appendix, Diagram 2). ${ }^{92}$

The tradition of Chinese funerary art that served ancestral worship for centuries was not pushed aside by the Buddhist structures, but remained as a parallel theme at Xuezhuang. To the deceased, his postmortem identification was complex. Attending the Buddha in an outlandish space was only half of the story; being an ancestor with power, glory, and virtue - as the processions and exemplary paragons display - in the underworld was the other half. In this view, we can see that the tomb at Xuezhuang was made neither merely for Buddhist worship as a caitya or a votive stele, nor exclusively for the ancestral cult as a traditional tomb, but is of a mixed, perhaps we can say "interspatial," nature, both in architectural and pictorial terms. ${ }^{93}$ It is probably one of the first examples in Chinese history in which the two religious practices are seen to inter- act with each other on an equal basis by means of art.

The double purpose made the stūpa or pagoda a perfect intersection of the Buddhist and the funerary traditions, for it made great sense to install a funerary marker and posthumous symbol of the Buddha into an underground structure that was both a Buddhist sacred space and a traditional burial.

The Immortal Ancestor Venerating the Immortal Buddha

At Xuezhuang, in spite of the fact that the funerary and the Buddhist structures stand in stark opposition to one another in terms of visual logic, they mesh together to serve a complex purpose.

Whereas all Buddhist-themed tiles including those of twin lions, twin dragons, and paired apsaras, as well as the brick pagoda, embrace symmetrical compositions without pointing to one 
direction, all the figures in the funerary tiles, except the narrative illustrations of the virtuous paragons, are oriented either leftward or rightward. Whereas the symmetrical Buddhist structures converge toward a vertical central axis running between the peak of the vaulted ceiling and the floor, the funerary structure points horizontally to the entrance. Whereas the Buddhist structures are essentially static and atemporal, the funerary structure with the procession implies movement and time. The almost total contradiction in visual logic ultimately derives from the structural and com- positional difference between Buddhist temples and traditional Chinese burials.

However, in a couple of places the parallel Buddhist and funerary structures mesh with each other. One of these occurs in the front. As the warriors protect the entry into both the Buddhist and the funerary structures, they also replace the attending bodhisattvas in the simulated Buddhist votive "stele" (see Figs. 3, 4).

And the other, more important locale where the Buddhist and funerary structures join together is the now totally disintegrated coffin once containing the deceased's body, because the coffin took a double position in containing the Buddhist worshipper who lay before the pagoda in the simulated votive "stele," and being the seat of the ancestor (wei 位) in the funerary structure. ${ }^{94}$ The double position overlaps the two subjective centers at Xuezhuang: the pagoda (as the body of the Buddha) and the deceased's body. The aniconic pagoda dominates the Buddhist worship and commands other Buddhist motifs set in the walls. Lying humbly low before the pagoda, meanwhile, the deceased's body commands all the non-Buddhist images that either flank or depart from it. Physically adjacent to each other, the two centers are organically bound together as the worshipped, namely the Buddha, and as the worshipper(s), or the deceased, in the Buddhist structure.

But what does it mean to have the deceased's body lie before the stūpa or pagoda in the tomb, which was supposed to be the deceased's posthumous home? I suggest that this design welded together two popular beliefs at the time, one in the posthumous meeting of the deceased with the Buddha, and one in the stūpa or pagoda as the imperishable Buddha in the state of nirvāna, which corresponds to the traditional Chinese understanding of death and immortality.

Ancestors and the Buddha were related concepts in early medieval China. During the fifth to sixth centuries, people widely hoped that they would attend the audience of the Buddha after death. Numerous inscriptions made in contemporary Buddhist votive steles express this popular belief. In the concluding prayer of the inscriptions, the patrons usually wish their deceased parents to be reborn in "the wonderful and happy land in the West" (xifang miaole guotu 西方妙樂國土), a paradise where they would “constantly meet with the Buddha” (chang yu fo hui 常與佛會), that is, Amitābha, the principal buddha of the Pure Land sect. ${ }^{95}$ Because this must happen in the Western paradise, an alien place outside of China, it was clearly unrealistic and fantastic. But an exotic burial, such as the Xuezhuang tomb, that housed both the Buddha and the deceased as worshipper precisely turned such a fantasy into reality.

The idea of posthumous meeting with Amitābha stated in the votive inscriptions was known to and perhaps even shared by the designer of the Xuezhuang tomb, ${ }^{96}$ located in the region of Xiangyang 襄陽, a prosperous center for Buddhism during the Six Dynasties. ${ }^{97}$ Only 100 miles to the north of Xuezhuang is Luoyang 洛陽, the second capital of the Northern Wei, which was a national center for making Buddhist votive steles with such wishful inscriptions during the early sixth century. ${ }^{98}$ As both Yang and Juliano have observed, many Buddhist elements in the Xuezhuang tomb were derived from Longmen 龍門 near Luoyang, where numerous Buddhist cave temples were constructed about the same time. ${ }^{99}$ 


\section{Conclusion}

Let me conclude by emphasizing two significant points. The first is historical. The Xuezhuang tomb represents a new concept of trans-religious interaction between Buddhism and ancestral worship in early medieval China. During the Eastern Han, individual Buddhist elements were subordinate to the tomb predominantly conceptualized as the deceased's secular happy home under a sacred heaven inhabited by gods in an everlasting other world. At Xuezhuang, this unified cosmic picture of "heaven, earth, and people" was broken, as the deceased was situated as a worshipper before the pagoda, the permanent Buddha, in his burial. The new intervention of a Buddhist context challenges our convention- al ideas of Chinese tombs: the tomb occupant now is no longer the sole host in the underground brick structure (as his posthumous home), because he is also a guest in a simulated Buddhist structure.

Although brick pillared tombs went out of fashion after the sixth century, the idea of including brick pagodas in the tomb architecture did not die with it. For example, a mid-Tang brick tomb excavated in 1998 in Beijing, dated to 759, contains a high-relief pagoda in the west wall, which suggests a renewal of this practice.100 Similar efforts of synthesizing Buddhist and funerary structures through architecture and its material content revived in north China during the tenth to eleventh centuries. ${ }^{101}$ These later examples, I believe, derive their conceptual basis ultimately from the Xuezhuang and other similar tombs from the early medieval period.

The second point concerns methodology. By demonstrating how Buddhist and funerary conventions unite in one physical space that we conventionally call a "tomb," this essay sets its analytical focus on the arrangement of the ensemble of material and visual motifs in the architectural space rather than on a few so-called Buddhist elements in Chinese tombs. The structural logic embedded in the tomb design demonstrates how traditional Chinese eyes, oriented in the "transparent view," were inclined to situate either Buddhist or funerary motifs in larger spatial settings I have called "structures." Thus the architectural space was not an empty gallery to contain images as collected exhibits. Quite contrary to this modern museum habit of thinking, the Xuezhuang space was dependent on Buddhist and funerary elements and was collectively shaped by them. The interspatial nature makes the tomb an ideal site for realizing the deceased's complex identification in the after- life.

The deceased person at Xuezhuang, whose physical remains and epitaph have not survived, might have been a devout Buddhist believer, who resorted to art to fulfill a last dream: to die with the Buddha. This proposition has two implications. On the one hand, it means both the tomb occupant and the Buddha, symbolized by the pagoda, were dead. But on the other hand, they must stay immortal together and forever. After the tomb was built, the coffin laid, and the door shut, the clock in the brick chamber stopped ticking in the middle of a never-ending meeting between the Buddha and his faithful disciple in the fantastic underground space shared by them both.

Appendix: Reconstruction of Painted Tiles in the Walls

My reconstruction is conducted on the basis of the following principles. (1) Among the surviving tiles, almost all human figures, animals, and vehicles on the non-Buddhist tiles bear a definite direction or facing, either leftward or rightward. ${ }^{102}$ For example, all the images on the surviving 
tiles set in the east wall are turned to the right and thus oriented toward the tomb entrance (see Diagram 1). The consistent outward facing in tombs during this period suggests that those images set in the west wall should have been oriented uniformly to the left, also in the direction of the entrance. The excavators of two other relatively well- preserved tombs have noted that in the intact pictorial tiles the figures all "face the tomb entrance." 103 This norm enables us to identify in which walls the displaced tiles were initially set.

(2) The surviving tiles in the walls demonstrate a strong symmetrical order. For example, in the first pair of pillars erected just inside the entrance in the passageway a tile bearing the image of two confronting lions in the east mirrors precisely its counterpart set in the west. Else- where, the tiles of ox-carts in the ninth pair of pillars follow the same rule. Such a symmetrical arrangement of tiles was customary in contemporaneous tombs, including the imperial southern Qi 齊 (479502) tombs, as Diagram 1 shows. ${ }^{104}$ It can be reasonably assumed that the tiles in the Xuezhuang tomb should have followed the same symmetrical pattern.

(3) Contemporaneous tombs such as the Southern Qi imperial tombs again offer parallels as to how these images should be organized. Set in the side walls of the passageway are pairs of lions and guardians; in the main chamber earthly processions including footed warriors, atten- dants carrying (ritual) objects, and groups of musicians appear in the lower register, while celestial figures including the Four Directional Dei- ties (sishen), apsaras, and virtuous paragons occupy the top register. This general arrangement of the ensemble of tiles, I assume, was like- wise followed at Xuezhuang. Following these three principles, the damaged Xuezhuang walls can be tentatively restored as in Diagram 2. ${ }^{105}$

1) Chen Dazhang 陳大章, “Henan Dengxian faxian Beichao qise caihui huaxiangzhuan mu” 河南鄧縣發現北朝七色彩繪畫像磚墓, Wenwu 1958.6: 55-56, 77; Henan Sheng wenhuaju wenwu gongzuodui 河南省文化局文物工作隊, Dengxian caise huaxiangzhuan mu 鄧縣 彩色畫像磚墓 (Beijing: Wenwu chubanshe, 1958) (hereafter abbreviated as DCHZM).

2) Su Bai, “Sanguo liang Jin Nanbeichao kaogu” 三國兩晉南北朝考古, in Zhongguo da- baike quanshu: Kaoguxue 中國大百科全書-考古學, ed. Zhongguo dabaike quanshu zongbianji weiyuanhui 中國大百科全書總編輯委員會 (Beijing: Zhongguo dabaike quanshu chubanshe, 1986), 422. Liu Han 柳涵 (i.e., Yang Hong 楊泓), “Dengxian hua- xiangzhuan mu de shidai he yanjiu” 鄧縣畫像磚墓的時代和研究, Kaogu 1959.5:256, 257; reprinted in Yang Hong, Han Tang meishu kaogu yu fojiao yishu 漢唐美術考古與佛教藝術 (Beijing: Kexue chubanshe, 2000), 103-14. More precise dating has been attempted. For example, Wei Zheng 韋正 suggested prior to 498, the year when Xuezhuang was annexed by the Northern Wei; see Wei Zheng, Wei Jin Nanbeichao kaogu 魏晉南北朝考古 (Beijing: Beijing daxue chubanshe, 2013), 163. But none of them has conclusive proof. For this reason, I will rely on Su's and Yang's more general dating throughout this essay. All dates in this paper are of the Common Era unless otherwise noted.

3) Annette Juliano, Teng-hsien: An Important Six Dynasties Tomb (Ascona, Switzerland: Artibus Asiae Publishers, 1980), 49; her discussion of the inscription is on p. 67-68, without providing a full transcription and translation of it. A full transcription is made in Wei, Wei Jin Nanbeichao kaogu, 159. My reading, however, is a little different from Wei's: 以三月握 
卒，以九月當陣，大眾十萬。既水，征馬惡，但務邊谷、口（米？）臺軍云。 以四月辭天子, 用此廿五本城部曲, 在路日久, 處處坐起, 給賜? 粟牛酒不

少, 以五月有口 （斬獲? ）。率眾家在吳郡, 自後…… “In the third month [I] commanded the troops. In the ninth month [I] reached the border. The great [army] num- bered a hundred thousand. After crossing the river, the campaigning horses were unfit. [I thus] concentrated on the military supplies of grains and (rice?) for the national army. In the fourth month [I] bid farewell to the Son of Heaven and employed the 25 regiments (buqu) of my home town. It has been many days since [we] were on the way; [we] have sat down and gotten up in many places; [we] have received a lot of millet, cows, and wine. In the fifth month (I killed and captured?). I led the families in Wu prefecture. Thereafter..."

4) DCHZM, 2.

5) Ibid.

6) Wei Zheng, “Shitan Nanchao muzang zhong de fojiao yinsu” 試談南朝墓葬中的佛教 因素, Dongnan wenhua 2010.3: 91-100; Nanjing daxue lishixi kaogu zhuanye南京大學歷史 系考古專業, Echeng liuchao mu 鄂城六朝墓 (Beijing: Kexue chubanshe, 2007), appendix 2.

7) Wuhan daxue lishixi kaogu zhuanye 武漢大學歷史系考古專業 and Ezhou shi bowuguan 鄂州市歷史博物館, “Ezhou shi Zelin Nanchao mu” 鄂州市澤林南朝墓, Jianghan kaogu 1991.3: 37-46. Early forms of such structures first appeared in tombs near Echeng during the early Eastern Jin 晉 dynasty (317-420). In Tangtoujiao 塘頭角 Tomb 13, dated to the early fourth century, the rear wall bears a conspicuous stepped structure, anticipating those found at Zelin two centuries later; see Hubei sheng wenwu kaogu yanjiusuo 湖北省文物考 古研究所, “Hubei Ezhou shi Tangtoujiao Liuchao mu” 湖北鄂州市塘頭角六朝墓, Kaogu 1996.11: 1-24, esp. p. 8, fig. 10. Another early example, located at the Guojiaxiwan 郭家細灣 cemetery not far away from Tangtoujiao, is different. The rear wall of Tomb 10, dating from the first half of the fourth century, yielded a stepped brick form, crowned by a semicircular "roof" rather than by a spire; see Huang Yijun 黃義軍, Xu Jinsong 徐勁松, and He Jianping 何建萍, “Hubei Ezhou Guojiaxiwan Liuchao mu” 湖北鄂州郭家細灣六朝墓, Wenwu 2005.10: 35-46. The levels of this pagoda, unlike those at Tangtoujiao, are indicated by vertically alternating widthwise and lengthwise brick courses. With a semicircular top and a rectangular bottom, the whole brick structure resembles a traditional Indian stūpa more strongly than it does a Chinese pagoda.

8) A partially damaged tomb brick dated to the second or third century was found in Sich- uan with a stamped pagoda image on it; see Xie Zhicheng 謝志成 “Sichuan Handai huax- iangzhuan shang de fota xingxiang” 四川漢代畫像磚上的佛塔形象, Sichuan wenwu 四川 文物 1987.4: 62-64. A well-preserved pottery model, 104 centimeters tall, was recently excavated in present-day Caiyue in Xiangyang, Hubei province; see Xiangfan shi wenwu kaogu yanjiusuo 襄樊市文物考古研究所, “Hubei Xiangfan Fancheng Caiyue Sanguo mu fajue jianbao” 湖北襄㚞㚞城菜越三國墓發掘簡報, Wenwu 2010.9: 4-19. For more such Bud- dhist motifs in Eastern Han tombs, see Yu Weichao 俞偉超, “Dong Han fojiao tuxiang kao" 東漢佛教圖像考, in his Xian Qin liang Han kaoguxue lunji 先秦兩漢考古學論集 (Beijing: Wenwu chubanshe, 1985), 157-69; Marylin M. Rhie, Early Buddhist Art of China and Central Asia: Later Han, Three Kingdoms, and Western Chin in China and Bactria to Shan-shan in Central Asia (Leiden: Brill, 1999), 33-47. 
9) For latest surveys of early medieval Chinese tombs, see Albert Dien, Six Dynasties Civilization (New Haven: Yale Univ. Press, 2007), 76-162; Wei, Wei Jin Nanbeichao kaogu, 76-256, particularly 156-63.

10) For a general history of Indian stūpas, see A.H. Longhurst, The Story of the Stūpa (New Delhi: Asian Educational Services, 1979); for symbolisms of stūpas, see Adrian Snodgrass, The Symbolism of the Stūpa (Ithaca: Cornell Univ. Press, 1985), and The Stūpa: Its Religious, Historical and Architectural Significance, ed. Anna Libera Dallapiccola and Stephanie Zingel- Avé Lallemant (Wiesbaden: Franz Steiner Verlag, 1980); for Chinese pagodas and their relationship to the Indian prototypes, see Li Yumin 李玉珢, “Zhongguo zaoqi fota suyuan” 中國早期佛塔溯源, Gugong xueshu jikan 6.3 (1989): 75-104; Li Chongfeng 李崇峰, Zhong Yin fojiao shikusi bijiao yanjiu: yi tamiaoku wei hexin 中印佛教石窟寺比較研究一以塔廟 窟為核心 (Beijing: Beijing daxue chubanshe, 1997).

11) André Bareau, "La construction et le culte des stūpa d'après Vinayapitaka," Bulletin de l'École française d'Extrême-Orient 50 (1962): 229-74; Hirakawa Akira 平川彰, Shoki Daijō Bukkyō no kenkyū 初期大乘仏教の研究 (Tokyo: Shunjūsha, 1968); Gregory Schopen,

"Burial 'ad sanctos' and the Physical Presence of the Buddha in Early Indian Buddhism: A Study in the Archeology of Religions," Religion 17.3 (1987): 193-225.

12) Wu Hung, The Art of the Yellow Springs: Understanding Chinese Tombs (Honolulu: Univ. of Hawaii Press, 2009). For a general study of Chinese ancestral worship, see William Lakos, Chinese Ancestor Worship: A Practice and Ritual Oriented Approach to Understanding Chinese Culture (Newcastle upon Tyne: Cambridge Scholars Publishing, 2010); for a study focusing on early Chinese materials, see Kenneth E. Brashier, Ancestral Memory in Ancient China (Cambridge, Mass.: Harvard Univ. Asia Center, 2011).

13) By definition meaning "complex entities constructed of many parts," the word "struc- ture" theoretically harks back to Jacques Lacan's "symbolic order," or the "order of culture" in Claude Levi-Strauss's words. Such pre-given cognitive structures set up boundaries for what people could actually be and do through their construction of tombs. In the Lacanian view, the "imaginary" is associated with the idealized identification the subject desires beyond him or herself in the "other," whereas the "symbolic" defines the way in which the imaginary is structured and the desire channeled; see Jacques Lacan, Écrits: A Selection (Lon- don: Routledge, 1997), 11, 95, 327, 332; Claude Levi-Strauss, Elementary Structures of Kinship (Boston: Beacon Press, 1949), 32. In this essay, which is primarily art historical, however, I use the word "structure" in a more concrete way to describe such established complex models of Buddhist and funerary art as temples, votive steles, or mural tombs, which represent conventional ways of organizing individual elements such as pagodas or guardians, to make an organic work and artistic space. In this perspective these material "structures" determined what Buddhist and funerary art should look like to the Chinese audience.

14) On studies of the Buddhist elements in the Eastern Han and the Three Kingdoms Period, see Wu Hung, "Buddhist Elements in Early Chinese Art (2nd and 3rd centuries ad)," Artibus Asiae 47.3-4 (1986): 263-352; Erik Zürcher, "Han Buddhism and the Western Region," in Thought and Law in Qin and Han China, ed. W.L. Idema and Erik Zürcher (Leiden: Brill, 1990), 159; Stanly Abe, Ordinary Images (Chicago: Univ. of Chicago Press, 2002), 11-102. All these scholars hold relatively similar positions, identifying the Buddhist-looking motifs as Daoist iconographies camouflaged under exotic appearances without serious, definite Buddhist implications. 
15) For examples of such studies, see Wei, "Shitan Nanchao muzang zhong de fojiao yinsu;" Lin Shengzhi 林聖智, “Muzang, zongjiao yu quyu zuofang: shi lun Beiwei muzang zhong de fojiao tuxiang, ”墓葬, 宗教與區域作坊一試論北魏墓葬中的佛教圖像, Guoli Taiwan daxue meishushi yanjiu jikan 24 (2008): 1-66. For Buddhist motifs in Koguryǒ tombs, see Lee Jung Hyo and Choi Duk Kyung, "Gaogouli mushi bihua de fojiao yinsu: yu zhoubian diqu de bijiao yanjiu” 高句麗墓室壁畫的佛教因素-與週邊地區的比較研究, in 4-6 shiji de bei Zhongguo yu ouya dalu 4-6世紀的北中國與歐亞大陸, ed. Zhang Qingjie 張慶捷 (Beijing: Kexue chubanshe, 2005), 280-309.

16) First, it is important to clarify that the Xuezhuang brickwork is a representation not of, as some believed, "twin pagodas," but of one pagoda, for the two pilasters jointly represent one pagoda plinth instead of two separate ones (see Fig. 1) (Wei, "Shitan Nanchao muzang zhong de fojiao yinsu"). The interstice between the two pilasters represents the front entrance that opens into the pagoda. Moreover, the main body of the pagoda resting on the plinth is an inseparable unity that cannot be divided into two individual parts. The holes, including the rectangular ones on the two sides and the terraced ones in the center, evenly spread in the pagoda in form of doors and windows on each level. A close parallel to such brick pagodas is the freestanding Songyue 嵩获 Pagoda in present-day Dengfeng

登封, Henan province, which has been preserved since the sixth century; for an intro- duction to the pagoda, see Fu Xinian 傅喜年 ed., Zhongguo gudai jianzhushi 中國古代建 築史 (Beijing: Jianzhu gongye chubanshe, 2001), vol.2: 189-90.

17) DCHZM, 2-3.

18) In some tombs excavated at Echeng, the rear walls bear plain, simple brick pilasters without pagoda structures on top of them. In such tombs, the pilasters embrace the entire tomb from the back, the left, and the right to create a colonnade-like structure; see Nanjing daxue lishixi kaogu zhuanye, Echeng liuchao mu, 45-52.

19) Tombs featuring such pilasters are conventionally called "brick pillared tombs" (zhuan- zhu $\mathrm{mu}$ 磚柱墓) by Chinese archaeologists; see Wei Zheng, Liuchao muzang de kaoguxue yanjiu 六 朝墓葬的考古學研究 (Beijing: Beijing daxue chubanshe, 2011), 127-39. The earli-

est known examples were excavated in present-day Jiangxi province. This distinct architec- tural style soon spread to northwest Fujian, Guangdong, and the middle Yangzi River valley in the vicinity of Echeng; see Jiangxi sheng wenwu guanli weiyuanhui 江西省文物管理委 員會, “Jiangxi Nanchao Qingyunpu Han mu” 江西南朝青雲譜漢墓, Kaogu 1960.10: 24-29; Huang Yishou 黃匵專, “Jiangxi Qingjiang Wuling Dong Han mu” 江西清江武陵東漢墓, Kaogu 1976.5: 331-34; Luo Zongzhen 羅宗真, Liuchao wenwu 六朝文物 (Nanjing: Nanjing chubanshe, 2004), 135, 138, 143; Wei Zheng, “Jiangxi Liuchao mu zongshu” 江西六朝墓綜述, Nanfang wenwu 2009.4: 114-23, esp. 120.

20) Nanjing daxue lishixi kaogu zhuanye, Echeng Liuchao mu, 321. These pillared tombs also appeared in Guangdong during the Eastern Jin period, but were not as popular as in the Echeng area; see Guangdong sheng bowuguan 廣東省博物館, “Guangdong Gaoyao Jin mu he Boluo Tang mu” 廣東高要晉墓何博羅唐墓, Kaogu 1961.9: 488-90.

21) Fu Xinian, Zhongguo gudai jianzhushi, 2:304.

22) Nanjing daxue lishixi kaogu zhuanye, Echeng Liuchao mu, 322, appendix 2. Two very close examples to the Xuezhuang tomb were excavated at Xiaojiaying 肖家營 in Gucheng 
谷城 (Tomb 40), and Jiajiachong 賈家沖 in Xiangfan 衰樊, both in Hubei province; see Xiangfan shi kaogudui 衰枆市考古隊 and Gucheng xian bowuguan 谷城縣博物館, “Hubei Gucheng xian Xiaojiaoying mudi” 湖北谷城縣肖家營墓地, Kaogu 2006.11: 15-37; Xiangfan shi wenwu guanlichu 襄樊市文物管理處, “Xiangyang Jiajiachong huaxiangzhuan mu” 衰陽賈 家沖畫像磚墓, Jianghan kaogu 1986.1:16-32. For another similar tomb located in the vicinity of Nanjing, see Nanjing shi bowuguan 南京市博物館, “Nanjing Youfangqiao faxian yizuo Nanchao huaxiangzhuan mu” 南京油坊橋發現一座南朝畫像磚墓, Kaogu 1990.10: 898-902. 23) Wuhan daxue lishixi kaogu zhuanye and Ezhou shi bowuguan, "Ezhou shi Zelin Nanchaomu."

24) Despite this art history definition, it should be noted that the word caitya broadly means all religious edifices and sacred sites in India; see Sushila Pant, The Origin and Development of Stupa Architecture in India (Yaranasi: Bharata Manisha, 1976), $26 \mathrm{ff}$.

25) These three major types are (i) circular, (ii) apsidal and (iii) quadrilateral; see H. Sarkar, Studies in Early Buddhist Architecture of India (Delhi: Munshiram Manoharlal, 1966), 25-44; also Debala Mitra, Buddhist Monuments (Calcutta: Sahitya Samsad, 1971), 41; Recently, Suresh Vasant identified six types which were not essentially different; see "Tulja Leni and Kondivte Caitya-gṛhas: A Structural Analysis," Ars Orientalis 30, Supplement 1: Chāchājī: (2000): 23-32, esp. 23. On periodization, see Vidya Dehejia, Early Buddhist Rock Temples; a Chronology (Ithaca, N.Y.: Cornell Univ. Press, 1972).

26) For comprehensive surveys of these cave temples, besides the aforementioned Studies in Early Buddhist Architecture of India, see also James Burgess, The Cave Temples of India (London: W. Allen \& Co., 1880); James Fergusson, The Cave Temples of India (Delhi: Oriental Books Reprint Corp., 1969); Owen C. Kail, Buddhist Cave Temples of India (Bombay: D.B. Taraporevala Sons \& Co., 1975).

27) Kail, Buddhist Cave Temples of India, 18-27.

28) Ibid., 28-35.

29) For example, Ajanțā Caves 19, 26; see Walter M. Spink, Ajanta: History and Development, vol. 5: Cave by Cave (Leiden: Brill, 2006), 374, 283, figs. 24, 32.

30) James Fergusson, James Burgess, and R. Phene Spiers, History of Indian and Eastern Architecture, 2 vols. (Delhi, Munshiram Manoharlal, 1967), 1: 127. For the archaeological report of Ter, see Sir John Hubert Marshall, "Ter-Tagara," in Archaeological Survey of India, Annual Report 1902-03 (Calcutta: Office of the Superintendent of Governement Printing, India, 1904), 197ff; for the report of Chezārla, see Alexander Rea, Progress Report of the Madras Archaeological Survey, December 1888 and January 1889.

31) Susan Huntington, The Art of Ancient India: Buddhist, Hindu, Jain (New York: Weatherhill, 2001), 180; Percy Brown, Indian Architecture: Buddhist and Hindu Periods (Bombay: D.B.

Taraporevala Sons \& Co., 1965), 41; Ananda K. Coomaraswamy, History of Indian and Indonesian Art (New York: Dover Publications, 1965), 77; Adam Hardy, Indian Temple Architecture: Form and Transformation: the Karṇāța Drāviḍa Tradition, 7th to 13th Centuries (New Delhi: Indira Gandhi National Centre for the Arts: Abhinav Publications, 1995), 59, n. 20.

32) Marshall, "Ter-Tagara," 197.

33) Coomaraswamy, History of Indian and Indonesian Art, 77. A number of similar freestanding caityas, though not so well preserved, are found concentrated at Nagarjunakonda in southeastern India, dated between the third and sixth centuries; see Mitra, Buddhist Monu- ments, 47, 209; Sarkar, Studies in Early Buddhist Architecture of India, 34-37. Remains of another apsidal brick caitya hall were uncovered in the Gurubhaktakondu Hill; see Devap- rasad Ghosh, "The 
Development of Buddhist Art in South India," The Indian Historical Quar- terly 4.4 (1928): 724 40. For the excavation report, see Alexander Rea, "Buddhist Monasteries on the Gurubhaktakonda and Durgakonda Hills at Ramatirtham," Archaeological Survey Annual Report 1910-11, 78-81.

34) Coomaraswamy, History of Indian and Indonesian Art, 77; Brown, Indian Architecture: Buddhist and Hindu Periods, 41.

35) Marshall, "Ter-Tagara," 197-98.

36) On a gilded bronze votive altar dating from 477, a group of regularly spaced "rings" are fastened to the bundled bamboos which make the aureole and halo of the Buddha. Mat subara Saburō 松原三郎, Chūgoku Bukkyō chōkoku shiron 中國仏教彫刻史論, 4 vols.

(Tokyo: Yoshikawa kōbunkan 1995), 2: pl. 64.

37) For the maritime silk road connecting Ceylon, Indonesia, and China before and around the sixth century, see Max Deeg, "Maritime Routes in the Indian Ocean in Early Times According to Chinese Buddhist Texts," in Aspects of the Maritime Silk Road: From the Persian Gulf to the East China Sea, ed. Ralph Kauz (Wiesbaden: Harrassowitz, 2010), 153-58.

38) Although no Buddhist temples dating from the third to fourth centuries in south China survive today, textual sources suggest that once they existed in hundreds; see Kida Tomō 木 田知生, “Jiang Zhe zaoqi fosi kao: Zaoqi fojiao zaoxiang nanchuan xitong yanjiu” 江浙早期 佛寺考一早期佛教造像南傳系統研究, trans. Hu Fuxing, Dongnan wenhua 1992.1: 162-

74. It can be speculated that some Chinese Buddhist temples might have been built in the style of Indian caityas in the middle and lower Yangzi River valley, and might have served as direct models for the Xuezhuang and other related brick tombs.

39) For a survey of these steles, see Dorothy Wong, Chinese Steles: Pre-Buddhist and Buddhist Use of a Symbolic Form (Honolulu: Univ. of Hawaii Press, 2004).

40) On the distinction of such reversed U-shaped forms and its relationship to the Indian prototype, Siren remarks that "all the Chinese figures are placed in front of large nimbuses or aureoles in the form of pointed leaves, or like sections of bulbs. These nimbuses... sometimes... serve as backgrounds, and on them are engraved the round halos which surround the heads... Such nimbuses, or large glories, surrounding the whole figure, are unknown in Indian sculpture before the medieval period... It is, however, undeniable that the large aure- oles were further developed in Chinese sculpture than in the plastic art of any other Bud- dhist country, and it is particularly in the early sculptures, those made before the middle of the 6th century, that they are of greatest importance...It would be premature to express any definite theory about the origin of these large nimbuses; we can only surmise that they were first developed in painting and that their transfer to sculpture was mainly accomplished in the northern Buddhist countries and not in India." Osvald Sirén, Chinese Sculpture from the Fifth to the Fourteenth Century, 2 vols. (New York: Hacker Art Books, 1970), 1: xxxv-xxxvi.

41) Ibid., 1: 40, pl. 159.

42) Hayashi Minao 林巳奈夫, “Jūkan Hoshu no jyakkan o megutte” 獣鐶・鋪首の若干を めぐって, Tōhō gakuhō 57 (1985): 1-74.

43) Yagi Haruo 八木春生, “Hokagi jidai goki no Buk(Dō)kyō sōzō ni mirareru Kan minzoku no dentō ni tsuite” 北魏時代後期の仏(道)教造像に見られる漢民族の伝統図像につ い, Bukkyō bijutsu 245 (1999): 16. For a Han-dynasty prototype, see Zhongguo huaxiangshi quanji bianji weiyuanhui 中國畫像石全集編輯委員會, Zhongguo huaxiangshi quanji 中 國畫像石全集, 8 vols. (Ji'nan: Shandong meishu chubanshe, 2000), 3: pl. 210. 
44) Jean P. Vogel, Indian Serpent Lore, or, The Nāgas in Hindu Legend and Art (London, A. Probsthain, 1926), 47-92; T.V. Mahalingam, "The Nāgas in Indian History and Culture," Journal of Indian History 43 (1965): 1-70.

45) Yagi Haruo, “'Shō' ni tsuite no ichi kōsatsu: 'shō’ to shōsen shisō no kankei o chūshin toshite”「勝」についての一考察一「勝」と昇仙思想の関係を中心として, Biga-

ku bijutsushi ronshū 9 (1992): 69-134. For example, see Zhongguo huaxiangzhuan quanji bianji weiyuanhui 中國畫像磚全集編輯委員會, Zhongguo huaxiangzhuan quanji 中國 畫像磚全集, 3 vols. (Chengdu: Sichuan meishu chubanshe, 2006), 1: pl. 48.

46) Sometimes decorating the lintel of tomb doors during the Eastern Han dynasty (25-220), the image of sheng at Xuezhang continued the previous funerary art tradition and its reli- gious meaning; for example, see Zhongguo huaxiangshi quanji, 7: 82, pl. 104; Zhongguo huaxiangzhuan quanji, 48, pl. 67.

47) Hayashi On 林溫, Hiten to shinsen 飛天と神仙 (Tokyo: Shibundō, 1993), 28. For Indian representations of apsaras, see Akiyama Terufumi 秋山光文, “Kodai Indo ni okeru Hiten no zuzō”古代インドにおける飛天の図像, Nihon no bijutsu 330 (1993): 87-98; for Chinese and other Eastern Asian representations of apsaras, see Yoshimura Rei 吉村怜, "Nanchō tennin zuzō no hokuchō oyobi shūhen shokoku e no denpa” 南朝天人圖像の北朝及び周 邊諸國一の傳播, Bukkyō geijutsu 159 (1985): 11-29.

48) Burton Watson, trans., The Vimalakirti Sutra (New York: Columbia Univ. Press, 2000), 86-87.

49）Li Song 李淞, “Lüe lun Zhongguo zaoqi tianwang tuxiang jiqi xifang laiyuan” 略論中國 早期天王圖像及其西方來源, in his Chang' an yishu yu zongjiao wenming 長安藝術與宗 教文明 (Beijing: Zhonghua shuju, 2002), 113-16, 126-30.

50) Huntington, The Art of Ancient India, 99-100; Alexander Cunningham, The Stūpa of Bharhut: a Buddhist Monument Ornamented with Numerous Sculptures Illustrative of Buddhist Legend and History in the Third Century B.C. (London: W.H. Allen, 1879), 110, pl. xxxi.1; Dehe- jia, Early Buddhist Rock Temples; A Chronology, pl. 50.

51) Matsubara, Chūgoku Bukkyō chōkoku shiron, 2: pls. 98 a-b.

52) Another group of votive steles, mostly dated to the latter half of the sixth century, includes an airborne stūpa suspended in midair over the head of the Buddha. These stūpas, however, often identified as “Many Treasures Stūpa" (duobaota 多寶塔) according to the Lotus Sutra, were of a different nature. Like the flying apsarases who toss flowers in the sky to celebrate the Buddhist teaching, the flying duobaota also represents "a mighty voice prais- ing Sakyamuni's preaching to the multitides." For a discussion of the Many Treasures Stūpa in the Buddhist text, see Eugene Y. Wang, Shaping the Lotus Sutra: Buddhist Visual Culture in Medieval China (Seattle: Univ. of Washington Press, 2005), 3-4. For visual examples, see Sirén, Chinese Sculpture from the Fifth to the Fourteenth Century, 1: pls. 156, 162, 196b; Mat- subara, Chūgoku Bukkyō chōkoku shiron, 2: pls. 34b, 98a, 98b, 116a, 116b, 270a, 270b, 315, vol. 3, pls. 383a, 392a, 393b, 407, 418, 421, 423a, 427, 435, 438, 441, 445, 454, 471, 479.

53) Wu Hung, "The Transparent Stone: Inverted Vision and Binary Imagery in Medieval Chinese Art," Representations: Philosophy and Religion 46 (1994): 58-86. New study has revealed that this penetrating perspective was already in vogue during the second century.

54) For the image, see DCHZM, 31, pl. 40. With regard to position, these dragons usually shelter the Buddha's throne from above, like the Indian Nāga, but they occasionally crouch at a lower level to flank the central Buddha. Juliano noted the Buddhist use of the motif of twin 
dragons, as she commented: "Dragons in this position usually occur in pairs on tomb pillars, stelae, Buddhist cave temples, and small shrines. On either side of a niche in the Ku- yang cave at Lung-men are very similar dragon forms;" see Juliano, Teng-hsien, 43.

55) For images, see DCHZM, 27-28, pls. 33-34.

56) Ibid., 28, pl. 35.

57) Ibid., 20-21, pls. 20-21.

58) Ibid., 31, pl. 41.

59) Masaharu Anesaki, Buddhist Art in Its Relation to Buddhist Ideals, with Special Reference to Buddhism in Japan (Boston: Museum of Fine Arts, 1915), 8; Albert Grünwedel, Buddhist Art in India (Santiago de Compostela, S. Gupta, 1965), 55.

60) Juliano, Teng-hsien, 51. For the image, see DCHZM, 15, pl. 12.

61) DCHZM, 32-36; for a discussion, see Susan Bush, "Floral Motifs and Vine Scrolls in Chinese Art of the Late Fifth to Early Sixth Centuries A. D.," Artibus Asiae 38.1 (1976): 49-83.

62) For such examples, see Sirén, Chinese Sculpture from the Fifth to the Fourteenth Century, 1: pls. 156, 162, 196b; Matsubara, Chūgoku Bukkyō chōkoku shiron, 2: pls. 34b, 98a, 98b, 116a, 116b, 270a, 270b, 315, vol. 3, pls. 383a, 392a, 393b, 407, 418, 421, 423a, 427, 435, 438, 441, 445,454 , $471,479$.

63) Was it possible that Buddha images painted on perishable materials such as silk or paper might have once been hung before the pagoda at Xuezhuang? Could wooden statues of Buddhist icons be used? There has been no archaeological evidence from Xuezhuang or any other Chinese tombs that would suggest such practices. For example, no remains of iron nails or hooks on the walls or altars for statues were reported. I therefore tend to believe that no such images ever existed in Xuezhuang.

64) Whalen W. Lai, "The Mahāparinirvāna-Sūtra and its Earliest Interpreters in China," Journal of the American Oriental Society 102 (1982): 99-105; Tang Yongtong 湯用泮, Han Wei Liang Jin Nanbeichao fojiaoshi 漢魏兩晉南北朝佛教史 (Beijing: Beijing daxue chubanshe, 2011), 374-96; Wang Bangwei 王邦維, “Lüe lun Dacheng Dabo Niepanjing de chuan yi” 略論大乘大般涅槃經的傳譯, Chung-Hwa Buddhist Journal / Zhonghua foxue xuebao 6 (1993): 103-27. According to Lai Wenying 賴文英, the pagoda-shaped central pillars carved in Buddhist grottoes during the Six Dynasties represented the Dharma body and the nirvana doctrine; see Lai Wenying, "Zhong Tang Dunhuang shiku zaoxiang de niepan sixiang” 中唐 敦煌石窟造像的涅槃思想, Dunhuangxue jikan 2007.1:64-70. See also Sonya S. Lee, Surviving Nirvana: Death of the Buddha in Chinese Visual Culture (Hong Kong: Hong Kong Univ. Press, 2010), 146-51.

65) Shimoda Masahiro 下田正弘, Nehangyō no kenkyū: Daijō kyōten no kenkyū hōhō shiron 涅槃経の研究-大乘経典の研究方法試論 (Tokyo: Shunjūsha 1997), 90-152.

66) Tang, Han Wei Liang Jin Nanbeichao fojiaoshi, 374-75.

67) Sugimoto Takushū 杉本卓洲, Indo buttō no kenkyū: buttō sūhai no seisei to kibanインド 佛塔の研究一佛塔崇拜の生成と基盤 (Kyoto: Heirakuji shoten, 1984), 175-90.

68) Kenneth E. Brashier, "Longevity like Metal and Stone: The Role of the Mirror in Han Burials," T'oung Pao 81 (1995): 201-29.

69) Works on Chinese representations of immortality in Han-dynasty art are numerous. Just to give one example, Michael Loewe, Ways to Paradise: The Chinese Quest for Immortality (London: George Allen \& Unwin, 1979). 
70) For images, see DCHZM, 17, 19, pls. 15, 18.

71) Keith Knapp, Selfless Offspring: Filial Children and Social Order in Early Medieval China (Honolulu: Univ. of Hawai'i Press, 2005); Kuroda Akira 黑田彰, Kōshiden no kenkyū 孝子伝 の研究 (Kyoto: Hatsubai shibunkaku shuppan, 2001).

72) For these two stories, see the fourth-century Soushen ji 搜神記, ed. Wang Shaoying 汪紹楹 (Beijing: Zhonghua shuju, 1979), 136, and the seventh-century encyclopedia Yiwen leiju 藝文類聚 (Shanghai: Shanghai guji chubanshe, 1982), 20.369.

73) Scholars have noted that the phrase "Southern Mountain" (Nanshan) is an equivalent of "Mt. Shang” (Shangshan). Sheng Congwen 沈從文, “'Shangshan sihao' he 'Youran jian Nan- shan', “商山四皓” 和 “悠然見南山,” in idem, Huahua caocao tantan guanguan: Shen Con- gwen wenwu yu yishu yanjiu wenji 花花草草罈罈罐罐一沈從文文物與藝術研究文集

(Beijing: Waiwen chubanshe, 1994), 88-89.

74) For the story of these four recluses, see Shiji 史記 (Beijing: Zhonghua shuju, 1959), 55.2047; for their Daoist implication, see Wang Zijin 王子今, “Sihao’ gushi yu daojia de guanxi” “四皓” 故事與道家的關係, Renwen zazhi 2012.2 :96-109.

75) Zheng Yan 鄭岩, Wei Jin Nanbeichao bihuamu yanjiu 魏晉南北朝壁畫墓研究 (Beijing: Wenwu chubanshe, 2002), 106: 223-32; Machida Akira 町田章, “Nansei teiryō kō” 南齊帝 陵考, in Bunkazai ronsō: Nara kokuritsu bunkazai kenkyūjo sōritsu 30-shūnen kinen ronbunshū 文化財論叢一奈良国立文化財研究所創立30周年記念論文集, ed. Nara kokuritsu bunkazai kenkyūjo sōritsu 30-shūnen kinen ronbunshū kankōkai 奈良国立文化財研究所 創立30周年記念論文集刊行会 (Kyoto: Dōhōsha, 1983), 1071-1104.

76) Xin Lixiang 信立祥, Handai huaxiangshi zonghe yanjiu 漢代畫像石綜合研究 (Beijing: Wenwu chubanshe, 2000), 118-28; Sahara Yasuo 佐原康夫, “Kandai shidō gazō kō” 漢代祠 堂畫像考, Tōhō gakuhō 63 (1991): 14-16.

77) Hou Hanshu 後漢書 (Beijing: Zhonghua shuju, 1965), 64.2124.

78) Eulogies of this period often compared ancient exemplary figures, including the most famous "Seven Sages of the Bamboo Grove” (zhulin qixian 竹林七賢), to the deceased. Among many examples, see Pu Lang's 苻朗 (d.389) deathbed poem (“Linzhong shi”

臨終詩), in Jinshu 晉書 (Beijing: Zhonghua shuju, 1974), 114.2937; Han Gui's 韓軌 (d.555) tomb epitaph, in Yiwen leiju 46.822; Jiang Zong’s 江總 (519-594) lamenting poem for the death of Gu Yewang 顧野王 (519-581), in Yiwen leiju, 34.599.

79) Yang, "Dengxian huaxiangzhuan mu de shidai he yanjiu," 258.

80) Ni Run’an 倪潤安, “Lun liang Han siling de yuanliu” 論兩漢四靈的源流, Zhongyuan wenwu 1999.1:83-91; Ogata Toru 大形徹, “Shishin kō: Zenkan Gokan ki no shiryō o chūshin toshite” 四神考一前漢、後漢期の資料を中心として, Jinbungaku ronshū 15 (1997):

127-43. Although the Red Bird (zhuque 朱雀) carries an inscription next to it that identifies it as the phoenix (fenghuang 鳳凰), the iconography of this fantastic bird, holding a bead in its beak, agrees with that of the Red Bird; see DCHZM, 30, pl. 39.

81) For the images, see DCHZM, 29, pls. 36-37.

82) Ibid., 19, pl. 19.

83) Ibid., 30, pl. 38.

84) Chōsen Gahōsha 朝鮮画報社, Koguryŏ kobun pyŏkhwa 高句麗古墳壁画 (Tonggyŏng: 
Chosŏn Hwabosa, 1985), pls. 25-26. Another similar outbound procession with similarly equipped and posed soldiers can be found in an early fifth-century tomb at present-day Shaling in Datong, Shanxi province; see Datong shi kaogu yanjiusuo 大同市考古研 究所, “Shanxi Datong Shaling Bei Wei bihuamu fajue jianbao” 山西大同沙嶺北魏壁畫墓 發掘簡報, Wenwu 2006.10: 4-24.

85) Jinshu, 20.626. For examples in the south, see Zheng, Wei Jin Nanbeichao bihuamu yanjiu, 63-69; Xu Xianxiu's mural dated to 571 is an example in the north; see Taiyuan shi wenwu kaogu yanjiusuo 太原市文物考古研究所, Bei Qi Xu Xianxiu mu 北齊徐顯秀墓 (Beijing: Wenwu chubanshe, 2005).

86) Xi'an shi wenwu baohu kaogusuo 西安市文物保護研究所, “Xi'an Qujiang Cuizuyuan Xi Han bihuamu fajue jianbao” 西安曲江翠竹園西漢壁畫墓發掘簡報, Wenwu 2010.1: 32, fig. 17.

87) For examples, see Changzhou shi bowuguan 常州市博物館 and Wujin xian bowuguan 武進縣博物館, “Jiangsu Changzhou nanjiao huaxiang, huawenzhuan mu” 江蘇常州南郊 畫像, 花紋磚墓, Kaogu 1994.12:1097-1103, pl. 1.2.

88) For the image, see DCHZM, 12, 15, 16, 18, 22, pls. 6, 11, 13, 17, 22.

89) $\mathrm{Wu}$, Art of the Yellow Springs, 206-8.

90) Some contemporary stories reflect this notion. According to one of the stories, when a deceased person named Su Shao 蘇韶 (fl. early third c.) visited his son's home on the horseback in the daylight, his sons could not see him; see Wang Yin 王隱, Jinshu, in Jiujia jiu Jinshu 九家舊晉書 (Ji'nan: Qilu shushe, 2000), 229-31; for a detailed translation and discussion of this story, see Stephen R. Bokenkamp, Ancestors and Anxiety: Daoism and the Birth of Rebirth in China (Berkeley: Univ. of California Press, 2007), 39-44. In another story when a posthumous procession visited a scriber, the living host could only hear the sound of the music playing and the voice of the guest, whose form remained totally unseen; see Liu Yiqing 劉義 慶, Youminglu 幽明錄 (Beijing: Wenhua yishu chubanshe, 1988), 107-8.

91) For examples, see Zhongguo huaxiangshi quanji, 5:94-95, 180, 187.

92) $\mathrm{Ni}$, "Lun Liang Han siling de yuanliu," 85.

93) Introduced by Shannon Jackson in her study of Hull-House, the concept of the interspa- tial theorizes "the semiotic hybridity of interpreted spaces," in which "the legacies of various spaces intersected and overlaid themselves;" see Shannon Jackson, Lines of Activity Perfor- mance, Historiography, Hull-House Domesticity (Ann Arbor: Univ. of Michigan Press, 2001), 24. Whereas Jackson emphasizes the practical and performative aspect of spatial experience, in this essay I am more interested in the structural tension, or the overlapping, between originally heterogeneous spaces culminating in the brick pagoda.

94) For a discussion of the concept of wei in Chinese funerary art, see Wu, Art of the Yellow Springs, 76.

95) Hou Xudong 侯旭東, Wu liu shiji beifang minzhong fojiao xinyang 五六世紀北方民眾 佛教信仰 (Beijing: Zhongguo shehui kexue chubanshe, 1998), 150-52. According to Satō Chisui 佐藤智水, about one third of the extant Northern Dynasties inscriptions are dedicated to deceased parents; Satō Chisui, "Hokuchō zōzō meiki kō" 北朝造像銘記考, Shigaku zasshi 86.10 (1977): 1438. Around the latter half of the sixth century a new idea that the deceased parents and other sentient beings could eventually become enlightened became popular; see Katherine R. Tsiang, "Resolve to Become a Buddha (Chengfo)—Changing Aspi- 
rations and Imagery in Sixth-century Chinese Buddhism," Early Medieval China 13-14.2 (2008): 115-69.

96) Satō, "Hokuchō Zōzō meiki kō," 1431.

97) Erik Zürcher, The Buddhist Conquest of China (Brill: Leiden, 1959), 180-239.

98) Hou, Wu liu shiji beifang minzhong fojiao xinyang, 107-8.

99) Yang, "Dengxian huaxiangzhuan mu de shidai he yanjiu," 256; Juliano, Teng-hsien, 29-30, $32,34,43,53-54$.

100) Wang Ce 王策, “Yanjing qichechang chutu de Tangdai muzang” 燕京汽車廠出土的 唐代墓葬, Beijing wenbo 1999.1, unpaginated color illustrations.

101) For Buddhist elements in Liao tombs, see Li Qingquan 李清泉, “Zhenrong ouxiang yu dojiaoxing muzang: cong Xuanhua Liaomu kan zhonggu sangzang liyi meishu de yici zhuanbian”真容偶像與多角形墓-從宣化遼墓看中古喪葬禮儀美術的一次轉

變, Yishushi yanjiu 8 (2006): 433-82.

102) Not all tiles from this tomb were set in the side and rear walls and were visibly exposed, because some of them were never used but concealed in a wall (fengmenqiang 封門牆) that blocked the entrance. These extra tiles are all plain and unpainted, whereas those used to decorate the walls all bear polychrome pigments. So this helps us rule out those unused tiles, in a total of nine; see DCHZM, pls. 22-29, 38. Some other tombs also yielded such extra unused decorative tiles, indicating that the tomb builder must have bought more than enough decorative tiles and discarded some of them, perhaps after intentional selections, during the construction of the tomb. At the Jiajiachong tomb, which is so far the closest example to the Xuezhuang tomb, there are also two extra Guo Ju tiles sealed in the entrance; see Xiangfang shi wenwu guanlichu, "Xiangyang Jiajiachong huaxiangzhuan mu," 22. The same practice of using extra decorative tiles to seal the tomb entrance was reported of two late fifth-century imperial Qi tombs in Danyang, famously decorated with images of the

“Seven Sages of the Bamboo Grove;” see Nanjing bowuyuan 南京博物院, “Jiangsu Danyang xian Huqiao, Jianshan liangzuo Nanchao muzang” 江蘇丹陽县胡橋、建山两座南朝墓 葬, Wenwu 1980.2:10. At another sixth-century tomb in Yuhuatai 雨花臺 in Nanjing, four pictorial tiles representing outing scenes were constructed not in the tomb, but in the drain outside the tomb; see Nanjing shi bowuguan and Yuhuatai qu wenhua guangbo dianshiju 雨 花臺區文化廣播電視局, “Nanjing shi Yuhuatai qu Nanchao huaxiangzhuan mu” 南京市 雨花臺區南朝畫像磚墓, Kaogu 2008.6:45, 46.

103) Changzhou shi bowuguan 常州市博物館 and Wujin xian bowuguan 武進縣博物館, “Jiangsu Changzhou nanjiao huaxiang huawenzhuan mu” 江蘇常州南郊畫像花紋磚墓, Kaogu 1994.12:1100; Nanjing bowuyuan, “Jiangsu Danyang Huqiao Nanchao damu ji zhuanke bihua” 江蘇丹陽胡橋南朝大墓及磚刻壁畫, Wenwu 1974.2: 49-50.

104) Zheng, Wei Jin Nanbeichao bihuamu yanjiu, 77; Bush, "Floral Motifs and Vine Scrolls in Chinese Art of the Late Fifth to Early Sixth Centuries A. D.," 51, n. 9.

105) Besides the guardian tiles set in the lowest level of the decorative band of the interior walls the tomb must have contained thirty-five polychrome pictorial tiles, among which twenty-six were uncovered in the tomb while the other nine were lost. In these twenty-six tiles, thirteen remained in their original positions. I define three types of tiles: (1) those undisturbed tiles, marked in bold; (2) the displaced tiles, italic, and (3) missing tiles, italic with bracketed question marks. 
